\title{
Production, nutritional status and chemical properties of soils with addition of cattle manure, reactive natural phosphate and biotite schist in Massai cultivar
}

\author{
Adônis Moreira ${ }^{1}$, Nand Kumar Fageria ${ }^{2}$, Gilberto Batista de Souza ${ }^{1}$, Alfredo Ribeiro de Freitas ${ }^{3}$ \\ ${ }^{1}$ Embrapa Amazônia Ocidental, Caixa postal 319, CEP: 69010-970, Manaus, AM \\ 2 Embrapa Arroz e Feijão, Santo Antônio de Goiás, GO. \\ 3 Universidade Federal de São Carlos, São Carlos, SP.
}

\begin{abstract}
The objective of this work was to evaluate the effects of cattle manure, reactive natural phosphate and biotite schist on the soil fertility, yield and nutritional status of Megathyrsus spp. cv. Massai. The experiment was conducted under field conditions, in a dystrophic Red Yellow Latosol (Oxisol). It was used a randomized block experimental design with the following treatments: three natural reactive rock phosphate from Algeria (Djebel-Onk) doses $\left(0,100\right.$ and $200 \mathrm{~kg}^{-1}$ of $\left.\mathrm{P}_{2} \mathrm{O}_{5}\right)$, three biotite schist doses $\left(0,150\right.$ and $300 \mathrm{~kg} \mathrm{ha}^{-1}$ of $\left.\mathrm{K}_{2} \mathrm{O}\right)$ and three cattle manure doses $(0,20$ and $40 \mathrm{t}$ ha-1). The application of natural phosphate increased dry matter yield, however, application of cattle manure and biotite schist did not influence this variable. Foliar levels of nitrogen, potassium and magnesium (cattle manure), phosphorous and boron (natural rock phosphate) and potassium (biotite schist) were influenced by the applied fertilizer doses. Only the levels of phosphorous in the soil and in the plant and levels of magnesium and boron in the plant show interaction with dry matter yield of Massai cultivar.
\end{abstract}

Key Words: alternative sources, Megathyrsus spp., mineral nutrition, soil fertility

\section{Produção, estado nutricional e propriedades químicas do solo com aplicação de esterco bovino, fosfato natural reativo e biotita xisto na cultivar Massai}

\begin{abstract}
RESUMO - Objetivou-se avaliar os efeitos de esterco bovino, fosfato natural reativo e biotita xisto sobre a fertilidade do solo, a produção e o estado nutricional de Megathyrsus spp. cv. Massai. O experimento foi realizado em condições de campo, em Latossolo Vermelho Amarelo distrófico (Oxisol). O delineamento experimental utilizado foi o de blocos casualizados, com os seguintes tratamentos: três doses de fosfato natural reativo da Argélia, Djebel-Onk $\left(0,100\right.$ e $200 \mathrm{~kg} \mathrm{ha}^{-1}$ de $\left.\mathrm{P}_{2} \mathrm{O}_{5}\right)$, três doses de biotita xisto $\left(0,150\right.$ e $300 \mathrm{~kg} \mathrm{ha}^{-1}$ de $\left.\mathrm{K}_{2} \mathrm{O}\right)$ e três doses de esterco bovino $\left(0,20\right.$ e $\left.40 \mathrm{t} \mathrm{ha}^{-1}\right)$. A aplicação de fosfato natural aumentou a produção de matéria seca, enquanto as aplicações de esterco bovino e a biotita xisto não influenciaram esta variável. Os teores de nitrogênio, potássio e magnésio (esterco bovino), fósforo e boro (fosfato natural) e potássio (biotita xisto) nas folhas foram influenciados pelas doses de fertilizante aplicadas. Somente os níveis de fósforo no solo e na planta e os de magnésio e boro na planta apresentam interação com a produção de matéria seca da cultivar Massai.
\end{abstract}

Palavras-chave: fertilidade do solo, fontes alternativas, Megathyrsus spp., nutrição mineral

\section{Introduction}

In intensive cattle dairy system, pasture field grazing capacity could be improved by application of fertilizers, including limestone, sodium, phosphorous and potassium and micronutrients. Werner et al. (1996) recommend the use of 40, 100 and $60 \mathrm{~kg} \mathrm{ha}^{-1}$ of $\mathrm{N}, \mathrm{P}_{2} \mathrm{O}_{5}$ and $\mathrm{K}_{2} \mathrm{O}$ in new pasture fields set in soils with low fertility, while for its maintenance, 80,50 and $50 \mathrm{~kg} \mathrm{ha}^{-1}$ would be necessary, respectively.
Application of cattle manure and/or reactive natural rock phosphates revealed productivity increases in pasture fields (Scherer et al., 1984; Sanzonowiscz \& Goedert, 1986; Moreira \& Malavolta, 2001). However, in organic systems, the sources of potassium are restricted to ashes, potassium sulfate, vinasse (from sugarcane processing) and mulch (AAO, 2000), making necessary to find new alternative sources of $\mathrm{K}$.

Oliveira et al. (2006) and Castro et al. (2006) found that the application of crushed biotite schist or alkaline 
ultramaphic rocks to soybeans and sunflowers crops caused an increase on dry matter yield similar to that obtained with the application of potassium chloride.

Most of the Brazilian dairy pasture fields are planted with Urochloa spp. and Megathyrsus spp. In the case of Megathyrsus spp., the Massai cultivar, a natural hybrid of M. maximum and M. infestam, appears to be a promising alternative forage for tropical edaphoclimatic conditions, because of its low seasonal variation, good crude protein content and good growth even in soils with low natural fertility (Valentim et al., 2001).

The objective of this study was to evaluate the effect of cattle manure, reactive natural rock phosphate (RNRP) and biotite schist on soil fertility and production and on nutritional value of a hybrid of Megathyrsus spp., Massai cultivar.

\section{Material and Methods}

The experiment was performed in 2006 at the Embrapa Pecuária Sudeste above a dystrophic Red Yellow Latosol (Oxisol or Typic Hapludox - Fageria, 1989), with medium texture $\left(483 \mathrm{~g} \mathrm{~kg}^{-1}\right)$. After correction with dolomitic limestone [27.1\% of $\mathrm{CaO}, 17.5 \%$ of $\mathrm{MgO}$ and ECC $=92.1 \%$ (percent of effective calcium carbonate)] to raise the base saturation to $70 \%$ (Werner et al., 1996), the top layer $(0-20 \mathrm{~cm})$ presented the following chemical characteristics: $\mathrm{pH}$ in $\mathrm{CaCl}_{2}=6.0$; $\mathrm{P}=16.1 \mathrm{mg} \mathrm{dm}^{-3} ; \mathrm{K}=0.8 \mathrm{mmol}_{\mathrm{C}} \mathrm{dm}^{-3} ; \mathrm{Ca}=45.0 \mathrm{mmol}_{\mathrm{C}} \mathrm{dm}^{-3}$; $\mathrm{Mg}=21.0 \mathrm{mmol}_{\mathrm{C}} \mathrm{dm}^{-3} ; \mathrm{H}+\mathrm{Al}=22.0 \mathrm{mmol}_{\mathrm{C}} \mathrm{dm}^{-3}$; and CEC $=88.9 \mathrm{mmol}_{\mathrm{C}} \mathrm{dm}^{-3}$.

The treatments consisted of three doses $(0,100$ and $200 \mathrm{~kg} \mathrm{ha}^{-1}$ of $\mathrm{P}_{2} \mathrm{O}_{5}$ ) of reactive natural rock phosphate (RNRP) from Algeria (Djebel-Onk), with 29\% $\mathrm{P}_{2} \mathrm{O}_{5}(9 \%$ being soluble in citric acid) and $12 \%$ of $\mathrm{Ca}$, three doses $\left(0,150\right.$ and $300 \mathrm{~kg} \mathrm{ha}^{-1}$ of $\left.\mathrm{K}_{2} \mathrm{O}\right)$ of biotite schist (2.0 mm crushed): $\mathrm{pH}_{\mathrm{H} 2 \mathrm{O}}=8.5, \mathrm{~K}_{2} \mathrm{O}=4.3 \%, \mathrm{CaO}=2.8 \%, \mathrm{MgO}=$ $15.1 \%, \mathrm{P}_{2} \mathrm{O}_{5}=0.01 \%, \mathrm{PN}=0 \%$ and $\mathrm{SiO}_{2}=54.6 \%$, and three doses ( 0,20 and $\left.40 \mathrm{t} \mathrm{ha}^{-1}\right)$ of cattle manure: $\mathrm{N}=5.0 \mathrm{~g} \mathrm{~kg}^{-1}$, $\mathrm{P}=2.6 \mathrm{~g} \mathrm{~kg}^{-1}, \mathrm{~K}=6.0 \mathrm{~g} \mathrm{~kg}^{-1}, \mathrm{~S}=1.0 \mathrm{~g} \mathrm{~kg}^{-1}$ and $\mathrm{Ca}=2.0 \mathrm{~g} \mathrm{~kg}^{-1}$ (Berton, 1997). Full doses of natural rock phosphate, ${ }^{2} / 3$ of the cattle manure and $2 / 3$ of the potassic rock were incorporated to soil 20 days before planting. After the third cutting, the remaining potassic rock and cattle manure were applied as top dressing.

A randomized block design with confounding treatment was used, with one replicate (Gomes \& Garcia, 2002). The distribution of the treatments (cattle manure, natural rock phosphate and biotite schist) was the following: Block I, 000, 012, 021, 101, 110, 122, 202, 211 and 220; Block II, 001, 010, 022, 102, 120, 200, 212 and 221; Block III, 002, 011, 020,
112, 121, 201, 210 and 222, and an additional with cattle manure, natural rock phosphate and potassium chloride $\left(60 \% \mathrm{~K}_{2} \mathrm{O}\right)$, in proportions of $40 \mathrm{tha}^{-1}, 100 \mathrm{~kg} \mathrm{ha}^{-1}$ of $\mathrm{P}_{2} \mathrm{O}_{5}$ and $150 \mathrm{~kg} \mathrm{ha}^{-1}$ of $\mathrm{K}_{2} \mathrm{O}$. The quantities of $\mathrm{KCl}$ and cattle manure were used similarly in the treatments. The land plots were rectangular, 5.0 meters by 3.0 meters, with a useful area of $3.0 \mathrm{~m}^{2}$, and the plant samples were collected from a square of $1.0 \mathrm{~m}^{2}$ randomly chosen in the plots.

First cutting was carried out 60 days after sowing and six cuttings (harvest) were performed. After the harvest, the vegetable material was weighed and dried at $\pm 65^{\circ} \mathrm{C}$ to determine dry matter yield. Before planting and after each cutting (harvest), samples were taken from the topsoil at a 0-20 cm depth to determine the $\mathrm{pH}\left(\mathrm{CaCl}_{2}\right)$, available phosphorous and exchangeable potassium, calcium, magnesium and $\mathrm{H}+\mathrm{Al}$, soil organic matter and $\mathrm{S}-\mathrm{SO}_{4}$ (Raij et al., 2001). After each cutting, cattle were allowed to graze on the parts of the not sampled plots.

After drying, samples from the aerial parts were ground and submitted to chemical analyses. Total nitrogen was extracted by sulfur digestion and measured by the microKjeldahl method (Bataglia et al., 1983). Total P, K, Ca, Mg, $\mathrm{S}, \mathrm{Cu}, \mathrm{Fe}, \mathrm{Mn}$ and $\mathrm{Zn}$ were determined according to the method described by Malavolta et al. (1997).

The data were submitted to variance analysis (ANOVA) and the least square means obtained were compared by Tukey test and regression analysis at $p \leq 0.05$ (Gomes \& Garcia, 2002). Pearson correlation coefficients between dry matter yield (DMY) and levels of available and exchangeable elements in the soil and plants were also estimated.

\section{Results and Discussion}

A significant effect of natural rock phosphate application was observed on dry matter yield of Massai cultivar, while the use of up to $40 \mathrm{tha}^{-1}$ of cattle manure and $300 \mathrm{~kg} \mathrm{ha}^{-1}$ of $\mathrm{K}_{2} \mathrm{O}$ in the form of biotite schist and their interactions had no effect (Table 1). In case of reactive natural rock phosphate (RNRP), there was an increase of $25 \%$ in forage volume, which is equivalent to an estimated enhance of $2.3 \mathrm{t} \mathrm{ha}^{-1}$ year $^{-1}$.

Similar increases in dry matter yield with the addition of phosphorous on Urochloa decumbens were obtained by Yost et al. (1982) and Soares et al. (2000) by incorporating $150 \mathrm{~kg} \mathrm{ha}^{-1}$ of natural rock phosphate from North Carolina (30\% of $\mathrm{P}_{2} \mathrm{O}_{5}$ ) and $100 \mathrm{~kg} \mathrm{ha}^{-1}$ of reactive natural rock phosphate from Gafsa (28\% of $\mathrm{P}_{2} \mathrm{O}_{5}$ ), respectively. Similar quantities of triple superphosphate (soluble source $-40 \%$ of $\mathrm{P}_{2} \mathrm{O}_{5}$ ) were also obtained with the use of RNRP (Arad and North Carolina) by Moreira \& Malavolta (2001) with alfalfa 
Table 1 - Least square means of dry matter yield (DMY) of Massai cultivar obtained under different treatments

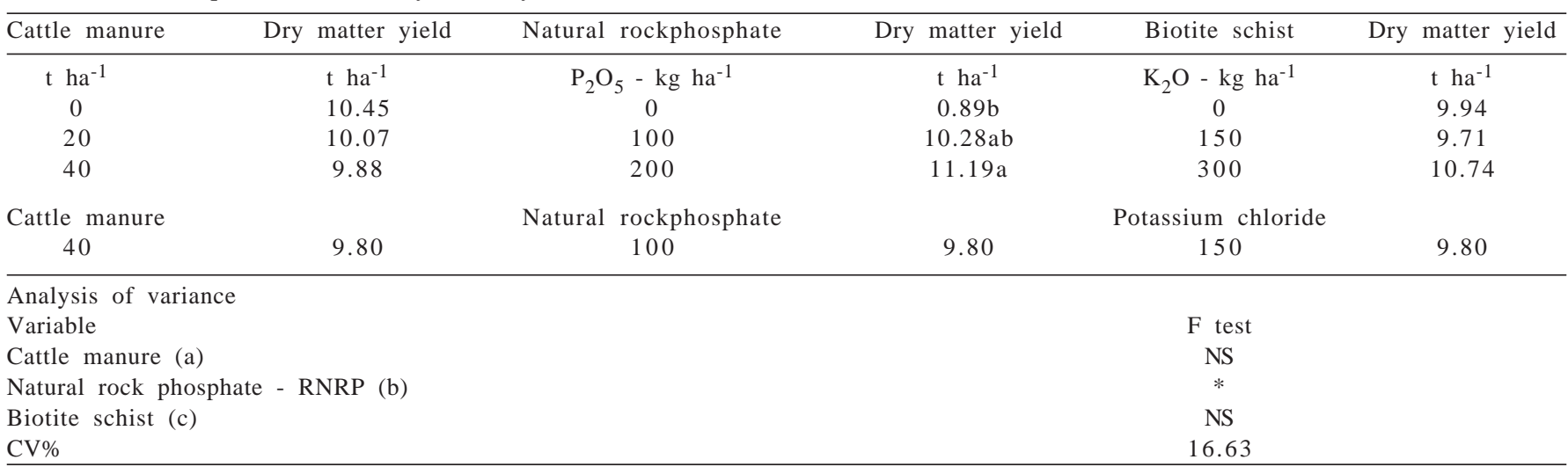

*, NS - Significant and non significant at $p \leq 0.05$.

${ }_{1}^{1}$ Means followed by the same letter in the each column are not significantly different at $p \leq 0.05$ level by Tukey test. $\Sigma$ of six harvest.

(Medicago sativa) and Brazilian butterfly peas (Centrosema pubescens Benth). These gains in yield are because of the function of phosphorous in plant metabolism, which plays an important role in energy storage and transfer, acting mainly in the form of adenosine diphosphate (ADP) and triphosphate (ATP) on respiration of the plants, photosynthesis, synthesis of nucleic acids and transport of ions through cell membranes (Hopkins, 1995; Fageria, 2009).

There was no significant increase in dry matter yield after application of cattle manure (Table 1) was probably because of the predominant organic form of the nitrogen present after incorporation of the manure into the soil (Kiehl, 1999). Nitrogen is assimilated from fresh manure only if mineralization or ammonification of the soil organic matter occur before, but in this period the nitrogen becomes immobilized by decomposing microorganisms, which is intimately related to the metabolism of carbon (Aita \& Giacomini, 2007). By reducing the availability of nutrients to the plants (mainly $\mathrm{C}_{4}$ plants), nitrogen assimilation is accelerated (Hopkins, 1995).

The effects of manure application have also been analyzed by other authors (Scherer et al., 2006; Oliveira et al., 2007), showing a significant increase in productivity through a quadratic effect, except at the highest doses. Machado et al. (1983) also observed the effect of cattle manure with the application of $20 \mathrm{tha}^{-1}$, where the yields of two harvests of irrigated rice (Oryza sativa) were similar to those of control plants.

In the case of biotite schist, although other authors have found significant enhancement of dry matter yield of sunflowers and soybeans (Castro et al., 2006; Oliveira et al., 2006), in other crops such as corn (Resende et al., 2006) there was no significant effect, regardless to the dose applied in it. According to Straaten (2007), in structure of biotite schist, potassium is present in the phyllosilicates between the tetrahedron layers of aluminum and octahedron layers of silicon or magnesium, avoiding release of the nutrient and availability to the plants. In this study, the dry matter yield with application of biotite schist was similar to that after KCl application (Table 1).

Seasonal variation of Massai cultivar forage yield was $61.2 \%$ in the spring and summer and $38.8 \%$ in the fall and winter. Lempp et al. (2001) found low seasonable variation of forage on this species, with $52.7 \%$ of yield in rainy season and $47.3 \%$ in dry season. This phenomenon, which occurs in most of tropical forage species, is determined mainly by climatic limitations, particularly those caused by water and temperature fluctuations (Müller et al., 2002).

The analyses of the dry matter yield showed that the addition of cattle manure raised the sodium and potassium levels and reduced the magnesium one (Table 2). The application of natural rock phosphate caused an increase in the phosphorous level and a reduction in the boron level, while the addition of biotite schist significantly raised only the potassium level (Table 2). The three types of fertilizers did not influence the levels of calcium, sulphur, copper, iron, manganese and zinc in the dry matter yield. (Table 2).

The addition of phosphate reduced the level of boron (Table 2) probably because of the nutrient own limitation caused by the positive interaction among phosphorus and boron which enhances the uptake. (Fageria, 2009).

In the absence of foliar concentration indicated as standard on the evaluation of the nutritional state of Massai cultivar in Brazilian conditions, the average concentrations in the plant tissue (aerial dry matter) presented the following order for macronutrients and micronutrients: $\mathrm{K}>\mathrm{N}>\mathrm{Mg}>\mathrm{P}>\mathrm{Ca}>\mathrm{S}$, and $\mathrm{Fe}>\mathrm{Mn}>\mathrm{Zn}>\mathrm{B}>\mathrm{Cu}$, respectively (Table 2). 
Table 2 - Least square means of N, P, K, Ca, Mg, S, B, Cu, Fe, Mn and Zn levels in aerial dry matter of Massai cultivar, under different treatments. Values are averages of six harvests

\begin{tabular}{|c|c|c|c|c|c|c|c|c|c|c|c|}
\hline \multirow[t]{2}{*}{ Variable } & $\mathrm{N}$ & $\mathrm{P}$ & K & $\mathrm{Ca}$ & $\mathrm{Mg}$ & S & B & $\mathrm{Cu}$ & $\mathrm{Fe}$ & $\mathrm{Mn}$ & $\mathrm{Zn}$ \\
\hline & \multicolumn{6}{|c|}{$\mathrm{g} \mathrm{kg}^{-1}$} & \multicolumn{5}{|c|}{$\mathrm{mg} \mathrm{kg}{ }^{-1}$} \\
\hline \multicolumn{12}{|c|}{ Manure, $\mathrm{t} \mathrm{ha}^{-1}$} \\
\hline 0 & 19.53b & 8.07 & $17.76 \mathrm{~b}$ & 6.17 & $17.77 b$ & 3.25 & 6.17 & 5.89 & 251.58 & 65.86 & 24.49 \\
\hline 20 & $20.68 \mathrm{ab}$ & 7.55 & $24.06 a$ & 6.34 & $13.29 a$ & 2.99 & 5.94 & 6.11 & 284.87 & 71.17 & 24.35 \\
\hline 40 & $20.95 a$ & 7.53 & $24.59 a$ & 6.25 & $12.91 \mathrm{a}$ & 2.99 & 6.04 & 6.13 & 297.61 & 62.70 & 24.60 \\
\hline $\mathrm{F}$ test & * & NS & $*$ & NS & $*$ & NS & NS & NS & NS & NS & NS \\
\hline \multicolumn{12}{|c|}{ Phosphate, kg ha-1 } \\
\hline 0 & 19.91 & $6.70 \mathrm{c}$ & 21.62 & 6.27 & 14.03 & 3.06 & 6.69a & 6.03 & 284.80 & 65.99 & 24.99 \\
\hline 100 & 20.63 & $7.64 b$ & 21.66 & 6.22 & 14.40 & 2.90 & $6.11 \mathrm{a}$ & 5.93 & 279.57 & 62.98 & 24.06 \\
\hline 200 & 20.63 & $8.82 \mathrm{a}$ & 23.13 & 6.26 & 15.53 & 3.25 & $5.35 b$ & 6.17 & 299.61 & 70.84 & 24.39 \\
\hline $\mathrm{F}$ test & NS & $*$ & NS & NS & NS & NS & $*$ & NS & NS & NS & NS \\
\hline \multicolumn{12}{|c|}{ Biotite, $\mathrm{kg} \mathrm{ha}^{-1}$} \\
\hline 0 & 20.32 & 8.04 & $21.09 \mathrm{~b}$ & 6.31 & 15.50 & 3.23 & 6.17 & 5.87 & 297.31 & 64.47 & 23.76 \\
\hline 150 & 20.40 & 7.12 & $21.13 b$ & 6.32 & 14.45 & 2.99 & 5.95 & 6.12 & 284.37 & 69.44 & 25.02 \\
\hline 300 & 20.44 & 8.00 & $24.19 a$ & 6.12 & 14.02 & 3.00 & 6.04 & 6.24 & 282.30 & 64.50 & 24.66 \\
\hline $\mathrm{F}$ test & NS & NS & * & NS & NS & NS & NS & NS & NS & NS & NS \\
\hline CV\% & 5.56 & 22.91 & 21.00 & 5.89 & 21.91 & 15.80 & 11.98 & 7.27 & 20.11 & 13.61 & 7.97 \\
\hline $\mathrm{CPK}^{(2)}$ & 20.37 & 6.97 & 27.26 & 5.65 & 11.27 & 2.67 & 6.01 & 5.88 & 307.77 & 88.19 & 21.81 \\
\hline
\end{tabular}

*, NS - Significant and non significant at $p \leq 0.05$. Natural rock phosphate - quantity in $\mathrm{P}_{2} \mathrm{O}_{5}$, biotite schist - quantity in $\mathrm{K}_{2} \mathrm{O}$.

${ }_{1}^{1}$ Means followed by the same letter in the same column are not significantly different at $p \leq 0.05$ by Tukey test.

${ }^{2} \mathrm{CPK}=$ Cattle manure $\left(40 \mathrm{Mg} \mathrm{ha}^{-1}\right)$, natural rock phosphate $\left(100 \mathrm{~kg} \mathrm{ha}^{-1}\right.$ of $\left.\mathrm{P}_{2} \mathrm{O}_{5}\right)$ and potassium chloride $\left(150 \mathrm{~kg} \mathrm{ha}{ }^{-1}\right.$ of $\left.\mathrm{KCl}\right)$.

Assuming as adequate the nutrient level in Megathyrsus spp., regardless of the cultivar, it was found that means of nitrogen $\left(20.4 \mathrm{~g} \mathrm{~kg}^{-1}\right)$, phosphorous $\left(7.5 \mathrm{~g} \mathrm{~kg}^{-1}\right)$, potassium (23.4 $\left.\mathrm{g} \mathrm{kg}^{-1}\right)$, magnesium (13.8 $\left.\mathrm{g} \mathrm{kg}^{-1}\right)$, sulphur $\left(3.0 \mathrm{~g} \mathrm{~kg}^{-1}\right)$, iron (292.9 $\left.\mathrm{mg} \mathrm{kg}^{-1}\right)$ and zinc $\left(7.5 \mathrm{mg} \mathrm{kg}^{-1}\right)$ were above those found by Gallo et al. (1974) and Pinkerton et al. (1997), while those of calcium $\left(6.1 \mathrm{~g} \mathrm{~kg}^{-1}\right), \mathrm{B}\left(6.0 \mathrm{mg} \mathrm{kg}^{-1}\right)$ and manganese (71.6 $\mathrm{mg} \mathrm{kg}^{-1}$ ) were considered low (Table 2). For nitrogen, the average concentration in the treatments was 32\% above those found by Lempp et al. (2001) for the same cultivar.

Application of cattle manure increased the content of soil organic matter and available $\mathrm{S}-\mathrm{SO}_{4}$ in the soil, while $\mathrm{pH}$, available phosphorus, potassium, calcium, magnesium and exchangeable $\mathrm{H}+\mathrm{Al}$ were not significant (Table 3 ). Addition of 20 and $40 \mathrm{tha}^{-1}$ of cattle manure increased the organic matter content by approximately 2 and $4 \mathrm{tha}^{-1}$ of carbon, respectively (Berton, 1997), without considering the mulch and manure left by the grazing animals after each cutting. In the case of the verified enhanced content of $\mathrm{S}^{-\mathrm{SO}_{4}}$ in the soil, it is estimated that over $95 \%$ of the sulphur in soils is found in organic compounds, with plant residues and animal droppings constituting the major source (Tabatabai \& Bremner, 1972).

The higher the rates of natural rock phosphate, the higher the levels of available $\mathrm{P}$, exchangeable $\mathrm{H}+\mathrm{Al}$ and soil organic matter (Table 3). In the case of exchangeable $\mathrm{H}+\mathrm{Al}$, considering that ammonia is one of the first products formed, the application of $\mathrm{P}$ must have been accelerated the initial decomposition of the soil organic matter, increasing the soil acidity. When the ammonia is converted into nitrate, $\mathrm{H}^{+}$ ions are released, temporarily raising the exchangeable and non-exchangeable acidity of the soil (Sousa et al., 2007).

The application of biotite schist raised the concentration of exchangeable potassium in the soil from 0.8 to $1.1 \mathrm{mmol}_{\mathrm{C}} \mathrm{dm}^{-3}$ (Table 3). Although this rock contains high quantities of $\mathrm{Ca}$ (2.8\%), $\mathrm{Mg}$ (15.1\%) and $\mathrm{SiO}_{2}(54.6 \%)$ and it has a high $\mathrm{pH}_{\mathrm{H} 2 \mathrm{O}}$ index (8.5), these variables were not affected by treatments. It is likely that the mineral structure of the rock avoids solubilization of these elements which are more easily absorbed at the surface of clays when compared to potassium (Straaten, 2007).

The dry matter yield $\left(\mathrm{t} \mathrm{ha}{ }^{-1}\right)$ presented a positive relationship with available $\mathrm{P}$-soil, $\mathrm{mg} \mathrm{dm}^{-3}(\hat{\mathrm{y}}=8.42+0.13 \mathrm{x}-$ $\left.0.0023 x^{2}, r=0.45\right)$ and P-plant, $g^{-1}(\hat{y}=1.24+1.46 x-$ $\left.0.040 \mathrm{x}^{2}, \mathrm{r}=0.66\right)$, and Mg-plant, $\mathrm{g} \mathrm{kg}^{-1}(\hat{y}=18.64+1.27 \mathrm{x}-$ $\left.0.44 \mathrm{x}^{2}, \mathrm{r}=0.61\right)$ and negative with the B-plant, $\mathrm{mg} \mathrm{kg}^{-1}$ $(\hat{y}=1.08-1.13 x, r=0.47)$. Maximum estimated yield was obtained when the concentration of available $\mathrm{P}$ in the soil and plants and of $\mathrm{Mg}$ in the plants were $29.5 \mathrm{mg} \mathrm{dm}^{-3}$, $18.3 \mathrm{~g} \mathrm{~kg}^{-1}$ and $14.3 \mathrm{~g} \mathrm{~kg}^{-1}$, respectively. For the foliar B, the lowest dry matter yield estimated was obtained with a foliar content estimated at $8.5 \mathrm{mg} \mathrm{kg}^{-1}$. These values could be used as a reference to define suitable levels of these elements in the soil and plants. Moreira et al. (2008), analyzing the $\mathrm{P}: \mathrm{Mg}$ ratio in alfalfa, observed a positive relationship between these elements and the DMY. 
Table 3 - Least square means of $\mathrm{pH}\left(\mathrm{CaCl}_{2}\right), \mathrm{P}, \mathrm{K}, \mathrm{Ca}, \mathrm{Mg}, \mathrm{H}+\mathrm{Al}, \mathrm{SOM}$ and $\mathrm{S}-\mathrm{SO}_{4}$ after six harvests of Massai cultivar

\begin{tabular}{|c|c|c|c|c|c|c|}
\hline & \multicolumn{3}{|c|}{ Cattle manure, $\mathrm{t} \mathrm{ha}^{-1}$} & \multirow[t]{2}{*}{ F test } & \multirow[t]{2}{*}{$\mathrm{CPK}^{(2)}$} & \multirow{2}{*}{$\begin{array}{l}\text { CV } \\
\%\end{array}$} \\
\hline & 0 & 20 & 40 & & & \\
\hline $\mathrm{pH}\left(\mathrm{CaCl}_{2}\right)$ & 5.92 & 5.72 & 5.73 & NS & 5.77 & 6.03 \\
\hline $\mathrm{K}\left(\mathrm{mmol}_{\mathrm{c}} \mathrm{dm}^{-3}\right)$ & 0.77 & 0.94 & 1.19 & NS & 3.07 & 19.27 \\
\hline $\mathrm{Ca}\left(\mathrm{mmol}_{\mathrm{c}} \mathrm{dm}^{-3}\right)$ & 41.22 & 36.33 & 35.67 & NS & 37.00 & 20.32 \\
\hline $\mathrm{Mg}\left(\mathrm{mmol}_{\mathrm{c}} \mathrm{dm}^{-3}\right)$ & 20.22 & 17.11 & 17.00 & NS & 19.33 & 20.73 \\
\hline \multirow[t]{2}{*}{$\operatorname{SOM}\left(\mathrm{g} \mathrm{kg}^{-1}\right)$} & $32.78 b$ & 34.33ab & $35.89 a$ & * & 37.00 & 9.77 \\
\hline & \multicolumn{3}{|c|}{ RNRP, kg ha ${ }^{-1}-\mathrm{P}_{2} \mathrm{O}_{5}$} & & & \\
\hline $\mathrm{pH}\left(\mathrm{CaCl}_{2}\right)$ & 5.82 & 5.78 & 5.78 & NS & & \\
\hline$P\left(\mathrm{mg} \mathrm{dm}^{-3}\right)$ & $14.56 b$ & $19.11 b$ & $26.33 a$ & $*$ & & \\
\hline $\mathrm{S}^{-\mathrm{SO}_{4}}\left(\mathrm{mg} \mathrm{kg}^{-1}\right)$ & 5.89 & 5.44 & 5.11 & NS & & \\
\hline \multirow[t]{3}{*}{$\operatorname{SOM}\left(\mathrm{g} \mathrm{kg}^{-1}\right)$} & $32.00 \mathrm{~b}$ & $35.22 \mathrm{a}$ & $35.78 \mathrm{a}$ & $*$ & & \\
\hline & \multicolumn{3}{|c|}{ Biotite schist, $\mathrm{kg} \mathrm{ha}^{-1}-\mathrm{K}_{2} \mathrm{O}$} & & & \\
\hline & 0 & 150 & 300 & & & \\
\hline $\mathrm{pH}\left(\mathrm{CaCl}_{2}\right)$ & 5.76 & 5.83 & 5.76 & NS & & \\
\hline$P\left(\mathrm{mg} \mathrm{dm}^{-3}\right)$ & 19.00 & 22.89 & 18.11 & NS & & \\
\hline $\mathrm{K}\left(\mathrm{mmol}_{\mathrm{c}} \mathrm{dm}^{-3}\right)$ & $0.80 \mathrm{~b}$ & $1.00 \mathrm{ab}$ & $1.10 \mathrm{a}$ & $*$ & & \\
\hline $\mathrm{Ca}\left(\mathrm{mmol}_{\mathrm{c}} \mathrm{dm}^{-3}\right)$ & 37.56 & 39.56 & 36.11 & NS & & \\
\hline $\mathrm{Mg}\left(\mathrm{mmol}_{\mathrm{c}} \mathrm{dm}^{-3}\right)$ & 18.11 & 18.22 & 18.00 & NS & & \\
\hline $\mathrm{H}+\mathrm{Al}\left(\mathrm{mmol}_{\mathrm{C}} \mathrm{dm}^{-3}\right)$ & 23.44 & 22.22 & 21.22 & NS & & \\
\hline $\mathrm{S}-\mathrm{SO}_{4}\left(\mathrm{mg} \mathrm{kg}^{-1}\right)$ & 4.11 & 6.44 & 5.89 & NS & & \\
\hline $\operatorname{SOM}^{4}\left(\mathrm{~g} \mathrm{~kg}^{-1}\right)$ & 34.56 & 34.11 & 34.33 & NS & & \\
\hline
\end{tabular}

*, NS - Significant and non significant at $p \leq 0.05$.

${ }_{1}^{1}$ Means followed by the same letter in the each line are not significantly different at $p \leq 0.05$ by Tukey test.

${ }^{2} \mathrm{CPK}=$ Cattle manure $\left(40 \mathrm{Mg} \mathrm{ha}^{-1}\right)$, Natural rock phosphate - RNRP $\left(100 \mathrm{~kg} \mathrm{ha}^{-1}\right.$ of $\left.\mathrm{P}_{2} \mathrm{O}_{5}\right)$ and potassium chloride (150 kg ha ${ }^{-1}$ of $\left.\mathrm{KCl}\right)$.

\section{Conclusions}

Natural rock phosphate is more efficient in increasing dry matter yield of Massai cultivar than both fresh cattle manure and biotite schist. Concentration of sodium and potassium in dry matter yield increases with cattle manure addition, while the natural rock phosphate enhances phosphorous and boron and the biotite schist the potassium concentration.

Application of cattle manure improve organic matter content and $\mathrm{S}-\mathrm{SO}_{4}$, the natural phosphate increase phosphorous level, soil organic matter and exchangeable $\mathrm{H}+\mathrm{Al}$, and the biotite schist the exchangeable potassium.

\section{Acknowledgments}

The authors thank Embrapa and the National Research Council (CNPq) for the funding to the first author, and the Fertilizer Company Heringer S/A for donating the natural rock phosphate from Algeria (Djebel-Onk).

\section{References}

ASSOCIAÇÃO DE AGRICULTURA ORGÂNICA - AAO. Manual de certificação da Associação de Agricultura Orgânica São Paulo: Associação de Agricultura Orgânica, 2000. 24p.

ABREU, M.F.; ABREU, A.A.; ANDRADE, J.C. Determinação de boro em água quente, usando aquecimento com microonda. In: RAIJ, B. van; ANDRADE, J.C.; CANTARELLA, H.; QUAGGIO, J.A. (Eds.). Análise química para avaliação da fertilidade de solos tropicais. Campinas: Instituto Agronômico de Campinas, 2001. p.231-239.

AITA, C.; GIACOMINI, S.J. Matéria orgânica do solo, nitrogênio nos sistemas de exploração agrícola. In: YAMADA, T.; ABDALLA, S.R.S.; VITTI, G.C. (Eds.). Nitrogênio e enxofre na agricultura brasileira. Piracicaba: Potafos, 2007. p.1-41.

BATAGLIA, O.C.; FURLANI, A.M.C.; TEIXEIRA, J.P.F. et al. Métodos de análise química de plantas. Campinas: Instituto Agronômico, 1983. 48p.

BERTON, R.S. Adubação orgânica. In: RAIJ, B. van; CANTARELLA, H.; QUAGGIO, J.A.; FURLANI, A.M.C. (Eds.). Recomendação de adubação e calagem para o Estado de São Paulo. Campinas: IAC, 1997. p.30-35.

CASTRO, C.; OLIVEIRA, F.A.; MOREIRA, A. et al. Rochas brasileiras como fontes alternativas de potássio para cultura do girassol. Espaço \& Geografia, v.9, n.2, p.17-31, 2006.

FAGERIA, N.K. Solos tropicais e aspectos fisiológicos das culturas. Brasília: Embrapa, 1989. 425p. 
FAGERIA, N.K. The use of nutrients in crops plants. Boca Raton: CRC Press, 2009. 430p.

GALLO, J.R.; HIROCE, R.; BATAGLIA, O.C. et al. Composição química inorgânica de forrageiras do Estado de São Paulo, Boletim de Indústria Animal, v.31, n.1, p.115-137, 1974.

GOMES, F.P.; GARCIA, C.H. Estatística aplicada a experimentos agronômicos e florestais. Piracicaba: FEALQ, 2002. 309p.

HOPKINS, W.G. Introduction to plant physiology. New York: John Wiley \& Sons, 1995. 464p.

KIEHL, E.J. Fertilizantes organominerais. Piracicaba: Degaspari, 1999. $146 p$

LEMPP, B.; SOUZA, F.H.D.; COSTA, J.C.G. et al. Capim-Massai (Panicum maximum cv. Massai): alternativa para diversificação de pastagens. Campo Grande: Embrapa Gado de Corte, 2001. 9p.

MACHADO, M.O.; GOMES, A.S.; TURATTI, A.L. et al. Efeito da adubação orgânica e mineral na produção do arroz irrigado e nas propriedades químicas e físicas do solo de Pelotas. Brazilian Journal of Agricultural Research, v.18, n.6, p.583-591, 1983.

MALAVOLTA, E.; VITTI, G.C.; OLIVEIRA, S.A. Avaliação do estado nutricional das plantas: princípios e aplicações. Piracicaba: Potafós, 1997. 319p.

MOREIRA, A.; HEINRICHS, R.; FREITAS, A.R. Relação fósforo e magnésio na fertilidade do solo, no estado nutricional e na produção da alfafa. Revista Brasileira de Zootecnia, v.37, n.6, p.984-989, 2008

MOREIRA, A.; MALAVOLTA, E. Fontes, doses e extratores de fósforo em alfafa e centrosema. Pesquisa Agropecuária Brasileira, v.36, n.12, p.1519-1527, 2001.

MÜLLER, M.S.; FANCELLI, A.L.; DOURADO-NETO, D. et al. Produtividade do Panicum maximum cv. Mombaça irrigado, sob pastejo rotacionado. Scientia Agrícola, v.59, p.427-433, 2002.

OLIVEIRA, A.P.; BARBOSA, A.H.D.; CAVALCANTE, L.F. et al. Produção da batata doce adubada com esterco bovino e biofertilizante. Ciência e Agrotecnologia, v.31, n.6, p.1722-1728, 2007.
OLIVEIRA, F.A.; CASTRO, C.; MOREIRA, A. et al. Eficiência da adubação residual com rochas brasileiras para cultura da soja. Espaço \& Geografia, v.9, n.2, p.69-84, 2006.

PINKERTON, A.; SMITH, F.W.; LEWIS, D.C. Pasture species. In: REUTER, D.J.; ROBINSON, J.B. (Eds.). Plant analysis an interpretation manual. Collingwood: CSIRO, 1997. p.287-346

RESENDE, A.V.; MACHADO, C.T.T.; MARTINS, E.S.; et al.Rochas como fontes de potássio e outros nutrientes para culturas anuais. Espaço \& Geografia, v.9, n.1, p.135-161, 2006.

SANZONOWISCZ, C.; GOEDERT, W.J. Uso de fosfatos naturais em pastagens. Planaltina: Embrapa-CPAC, 1986. 33p.

SCHERER, E.G.; CASTILHOS, E.G.; JUCKSCH, I. et al. Efeito da adubação com esterco de suínos, nitrogênio e fósforo em milho. Florianópolis: EMPASC, 1984. 26p.

SOARES, W.V.; LOBATO, E.; SOUSA, D.M.G. et al. Avaliação de fosfato natural de Gafsa para recuperação de pastagem degradada em Latossolo Vermelho-Escuro. Brazilian Journal of Agricultural Research, v.35, n.4, p.819-825, 2000.

SOUSA, D.M.G.; MIRANDA, L.N.; OLIVEIRA, S.A. Acidez do solo e sua correção. In: NOVAIS, R.F.; ALVAREZ VENEGAS, V.H.; BARROS, N.F. et al. (Eds.). Fertilidade do solo. Viçosa, MG: SBCS, 2007. p.205-274.

STRAATEN, P. van. Agroecology: the use of rocks for crops. Ontario: Enviroquest, 2007. 440p.

TABATABAI, M.A.; BREMNER, J.M. Distribution of total and available sulfur in select soils and soil profiles. Agronomy Journal, v.64, n.1, p.40-44, 1972.

VALENTIM, J.F.; CARNEIRO, J.C.; MOREIRA, P. et al. Capim Massai (Panicum maximum Jacq.): nova forrageira para diversificação das pastagens no Acre. Rio Branco: Embrapa Acre, 2001. 16p.

YOST, R.S.; NADERMAN, G.C.; KAMPRATH, E.J. et al. Availability of rock phosphate as measured by an acid tolerant pasture grass and extractable phosphorus. Agronomy Journal, v.74, n.3, p.462-468, 1982.

WERNER, J.C.; PAULINO, V.T.; CANTARELLA, H. et al. Forrageiras. In: RAIJ, B. van; CANTARELLA, H.; QUAGGIO, J.A. et al. (Eds.) Recomendação de adubação e calagem para o Estado de São Paulo. Instituto Agronômico de Campinas, 1996. p.245-258. (Boletim 100). 